\title{
Adsorption of penicillin by decaffeinated tea waste
}

\author{
Parvin Gharbani ${ }^{1,}$, Ali Mehrizad ${ }^{2}$, Ismail Jafarpour ${ }^{1}$ \\ ${ }^{1}$ Department of Chemistry, Ahar Branch, Islamic Azad University, Ahar, Iran \\ ${ }^{2}$ Department of Chemistry, Tabriz Branch, Islamic Azad University, Tabriz, Iran \\ *Corresponding author: p-gharbani@iau-ahar.ac.ir, parvingharbani@yahoo.com
}

\begin{abstract}
Removal of penicillin has been investigated using decaffeinated tea waste (DCTW). Decaffeination of tea waste was investigated using different methods. Results indicate that ozonation was the most effective process for removal of penicillin. Batch adsorption experiments were completed at various temperatures $\left(20,30\right.$, and $\left.40^{\circ} \mathrm{C}\right)$, DCTW dosages $(2,4,6,8$, and $10 \mathrm{~g}$ per $250 \mathrm{~mL})$, penicillin concentrations $(4,10$, and $14 \mathrm{mg} / \mathrm{L})$, and $\mathrm{pH}(3,7$, and 10$)$ conditions. Studies showed that adsorption reaches equilibrium within $40 \mathrm{~min}$. The main factor affecting adsorption of penicillin was the solution $\mathrm{pH}$, with maximum adsorption occurring at $\mathrm{pH} 3$. Higher adsorbent dosages and lower penicillin concentrations also resulted in higher percentages of penicillin removal. Results show that data obeyed the pseudo-first-order kinetic and Freundlich isotherm models. This process proves that low-cost DCTW could be used as a high performance adsorbent for removing penicillin from aqueous solutions.
\end{abstract}

Keywords: adsorption, caffeine, penicillin, isotherm, kinetic.

\section{INTRODUCTION}

Water is a precious environmental resource because it is used by nearly all living organisms; therefore, pollution of water resources may be a serious problem in all parts of the world. The pharmaceutical industry produces compounds that are toxic at trace concentrations if released to the environment in water or soil. Antibiotics are a sub-category of pharmaceuticals that may be released to the environment ${ }^{1}$. Methods for removing antibiotics from water or soil are being actively investigated; methods include coagulation \& GAC filtration ${ }^{2}$, biodegradation $^{3}$, biosorption ${ }^{4}$, and adsorption ${ }^{5}$, among others. Adsorption is a simple and economic method for removal of trace-level pollutants ${ }^{6}$. In recent years, adsorption onto effective and less expensive adsorbents has received more attention. If biomass is used as the adsorbent (i.e., bioadsorbent), the process is termed as bioadsorption. A desirable adsorbent would be natural, organic and abundant as a waste product from another process ${ }^{7}$. Many bioadsorbents such as bacteria, algae, yeasts, and fungi ${ }^{8}$, chicken feathers ${ }^{9}$, chitosan, and peat ${ }^{10}$ are used to remove organic and inorganic contaminants from aqueous solutions. Tea is a natural ingredient for popular drinks, worldwide; therefore, many tons of tea wastes are produced each year. Previous research demonstrated the capacity of tea wastes to adsorb pollutants, such as dyes ${ }^{11,12}$ and heavy metals ${ }^{13}{ }^{14}$, from aqueous solutions.

The purpose of this research is to study the removal of penicillin (PC) from aqueous solutions using decaffeinated tea waste (DCTW). This is studied by first removing caffeine from tea leave wastes to create DCTW, then investigating the use of DCTW as an adsorbent.

\section{EXPERIMENTAL}

\section{Material}

Tea waste was provided from commercial black tea of Lahijan, Iran. Caffeine, $\mathrm{HCl}$, and $\mathrm{NaOH}$ were purchased from Merck, CNTs were purchased from Research Institute of Petroleum Industry (RIPI) of Iran, and penicillin was obtained from Kimidaro Company, Iran.
Other analytical grade chemicals used in the experiment were obtained from various chemical suppliers.

\section{Preparation of tea waste}

In this study, DCTW was used as a bioadsorbent for removal of PC from aqueous solutions. Initially, samples of tea waste were washed several times with hot $\left(90^{\circ} \mathrm{C}\right)$ water to remove of color and soluble components.

Because of overlapping of caffeine with PC peaks in the UV region, it is necessary to remove caffeine from the tea waste. Methods for removal of caffeine from tea waste were investigated, including ozonation (flow $=5$ $\mathrm{L} / \mathrm{min}$ ), ultrasonic (frequency $=20 \mathrm{~Hz}$ ), UV radiation (30 watt), and adsorption onto SWCNTs $(200 \mathrm{mg} / \mathrm{L})$, MWCNTs (200 mg/L), SWCNTs-COOH (200 mg/L) and MWCNTs-COOH (200 mg/L). By comparing the results of decaffeination of tea, ozonation was found to be the most effective method. After drying of DCTW in $100^{\circ} \mathrm{C}$ for 1 hour, it was ground and stored in a dry place.

\section{Methods}

Adsorption experiments were done in a $250 \mathrm{~mL}$ Erlenmeyer flask on a stirrer. A solution with PC concentration of $5000 \mathrm{mg} / \mathrm{L}$ was prepared in distilled water. Generally, $2 \mathrm{~g}$ of DCWT were used with $10 \mathrm{mg} / \mathrm{L}$ of PC, and $\mathrm{HCl}$ and $\mathrm{NaOH}$ were used to adjust $\mathrm{pH}$ of the solution. The effects of parameters such as $\mathrm{pH}(3,7,10)$, contact time, PC concentration (4, 10, $14 \mathrm{mg} / \mathrm{L})$, DCTW dosage (2, $4,6,8,10 \mathrm{~g} / 250 \mathrm{~mL})$ and temperature $\left(20,30,40^{\circ} \mathrm{C}\right)$ were studied.

\section{Analytical methods}

All of the experiments were done on a magnetic stirrer for a period of $40 \mathrm{~min}$. Samples were withdrawn every $5 \mathrm{~min}$, then filtered using filter paper. The remaining PC concentration could be analyzed using a UV-Vis spectrophotometer (HACH-DR5000) at maximum wavelength of PC $\left(\lambda_{\max }=255 \mathrm{~nm}\right) \cdot q_{e}, q_{t}$, and \% Removal were obtained using the following equations:

$$
\begin{aligned}
& q_{t}=\frac{\left(C_{0}-C_{t}\right)}{m} \times V \\
& q_{e}=\frac{\left(C_{0}-C_{e}\right)}{m} \times V
\end{aligned}
$$


\%Removal $=\frac{\left(C_{0}-C_{t)}\right.}{C_{0}} \times 100$

\section{RESULTS AND DISCUSSION}

\section{Decaffeination of tea waste leaves}

Different physical and chemical methods (adsorption onto CNTs, $\mathrm{O}_{3}$, ultrasonic, UV) were investigated for their capacity to remove caffeine from tea waste. A solution containing $10 \mathrm{mg} / \mathrm{L}$ of caffeine was prepared and \% removal of caffeine was analyzed by different methods (Fig. 1).

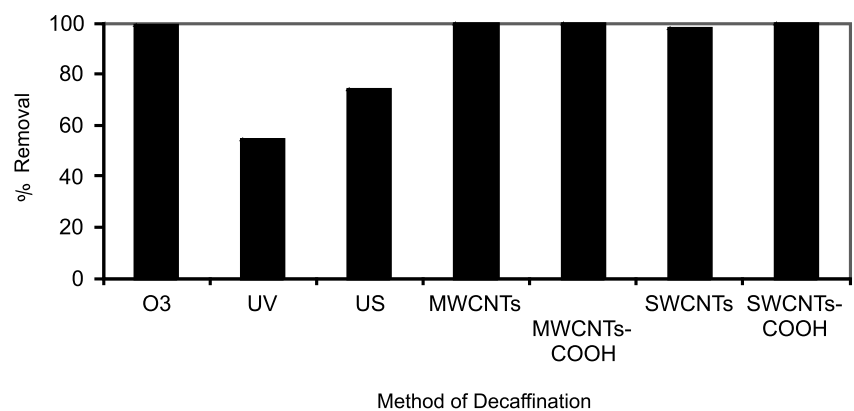

Figure 1. Comparative study of decaffeination of tea waste

Nearly $100 \%$ of the caffeine was removed by ozonation and CNTs after $30 \mathrm{~min}$ (shown in Fig. 1). Because the by-product of ozonation is $\mathrm{O}_{2}$, ozonation is selected as a preferred method for removal of caffeine from tea waste. After decaffeination of tea waste by ozonation, it was ground and dried in an oven for an hour. Then used as a bioadsorbent for removal of PC.

\section{Adsorption of PC onto DCTW}

Removal of PC by DCTW was evaluated at various contact times, $\mathrm{pH}$ values, concentrations of $\mathrm{PC}$, dosages of DCWT, and temperatures.

\section{Effect of contact time}

To study the effect of contact time for adsorption of PC onto DCTW, experimental was carried out using $250 \mathrm{~mL}$ of $\mathrm{PC}$ at a concentration of $10 \mathrm{mg} / \mathrm{L}$, and $2 \mathrm{~g}$ of DCTW at pH of 6.5 for $110 \mathrm{~min}$. As shown in Figure 2, rapid adsorption was observed at the beginning of the experiment until adsorption equilibrium was reached at

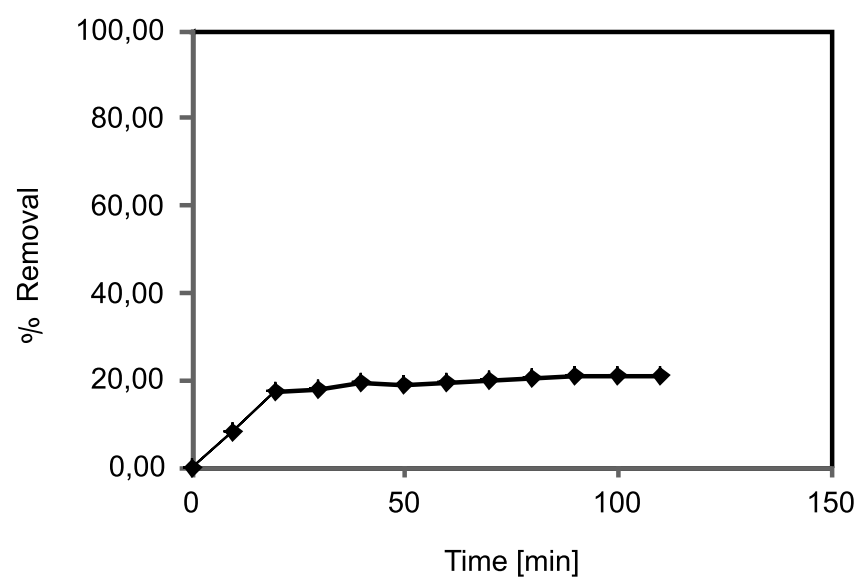

Figure 2. Effect of contact time on removal of $\mathrm{PC}$ by DCTW $[\mathrm{PC}] 0=10 \mathrm{mg} / \mathrm{L}$; [DCTW] $0=2 \mathrm{~g} /$ $250 \mathrm{~mL} ; \mathrm{pH}=6.5 ; \mathrm{T}=25^{\circ} \mathrm{C}$
40 min of contact time. Because additional adsorption did not occur after $40 \mathrm{~min}$, all experiments were carried out for $40 \mathrm{~min}$.

\section{DCTW dosage}

Figure 3 shows the effect of DCTW dosage on removal of $\mathrm{PC}$ at $\mathrm{pH}$ of 6.5 . Percent removal of $\mathrm{PC}$ was increased by increasing the DCTW dosage because higher adsorbent concentration resulted in a greater number of adsorbent particles, surface area of adsorbent and greater availability of adsorption sites ${ }^{15-16}$.

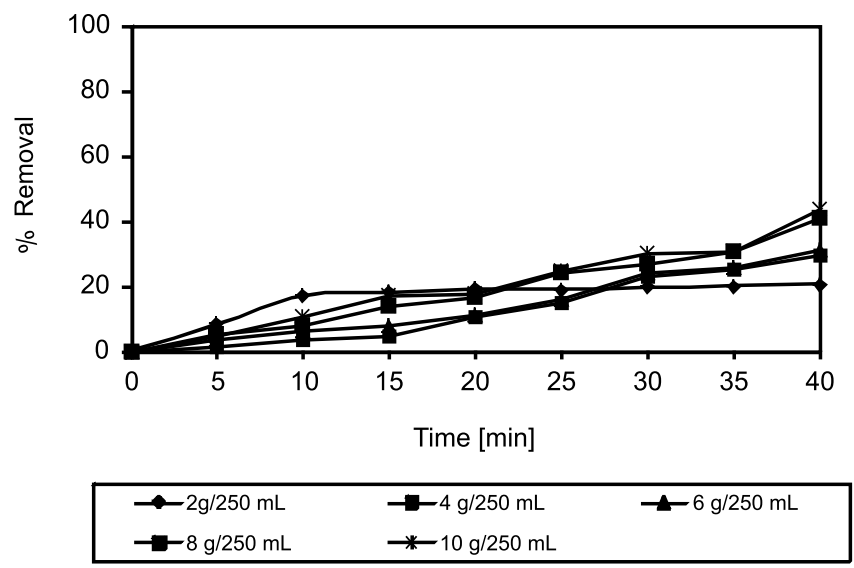

Figure 3. Effect of DCTW dosage on removal of PC by DCTW $[\mathrm{PC}] 0=10 \mathrm{mg} / \mathrm{L} ; \mathrm{pH}=6.5 ; \mathrm{T}=25^{\circ} \mathrm{C}$

\section{pH of solution}

One of the main factors affecting the adsorption process is $\mathrm{pH}$; therefore, adsorption studies were down at $\mathrm{pH}$ values of 3, 7, and 10 (illustrated in Fig. 4). It is clear that when $\mathrm{pH}$ increases from 3 to 10 , the $\%$ removal decreases from 39.30 to 30.11 . Whereas, the pHzpc of tea is around $4.2^{17}$ and the pKa of $\mathrm{PC}$ is 2.8 , the maximum adsorption of PC was observed at lower pHs. In fact at $\mathrm{pH}<4.2$, the surface of adsorbent became positive and there were few repulsions between PC and DCTW. By increasing the $\mathrm{pH}$, the surface charge on the adsorbent and PC became negative and repulsion increased. In summary, adsorption decreased by increasing $\mathrm{pH}$.
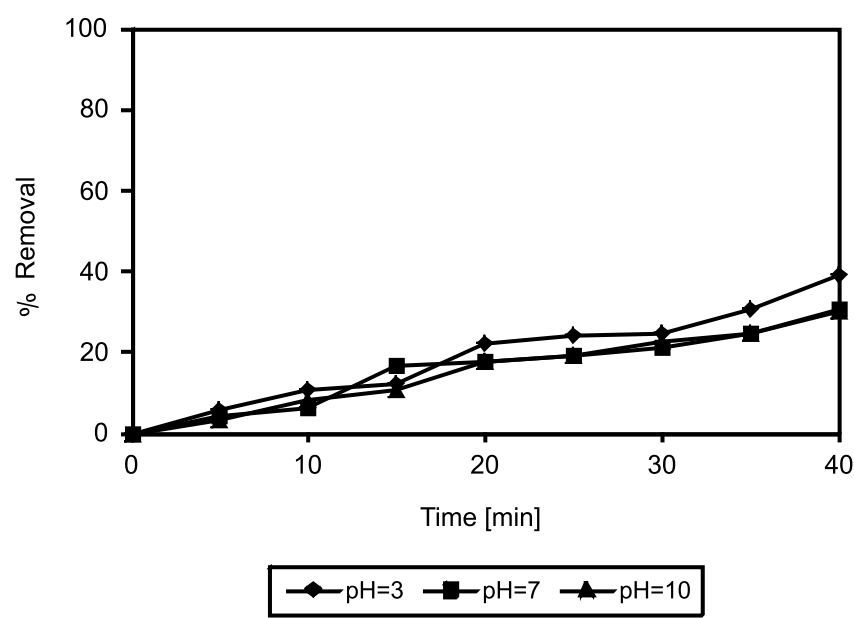

Figure 4. Effect of $\mathrm{pH}$ on removal of PC by DCTW [PC] $0=10 \mathrm{mg} / \mathrm{L}$; [DCTW] $0=2 \mathrm{~g} / 250 \mathrm{~mL} ; \mathrm{T}=$ $25^{\circ} \mathrm{C}$ 


\section{PC concentration}

Figure 5 shows the effect of PC concentration, whereby, increases in the $\mathrm{PC}$ concentration are due to decreases of PC adsorption onto DCTW. However, by increasing the adsorbate, available sites for adsorption become fewer, hence, the adsorption decreased ${ }^{\mathbf{1 8}}$.
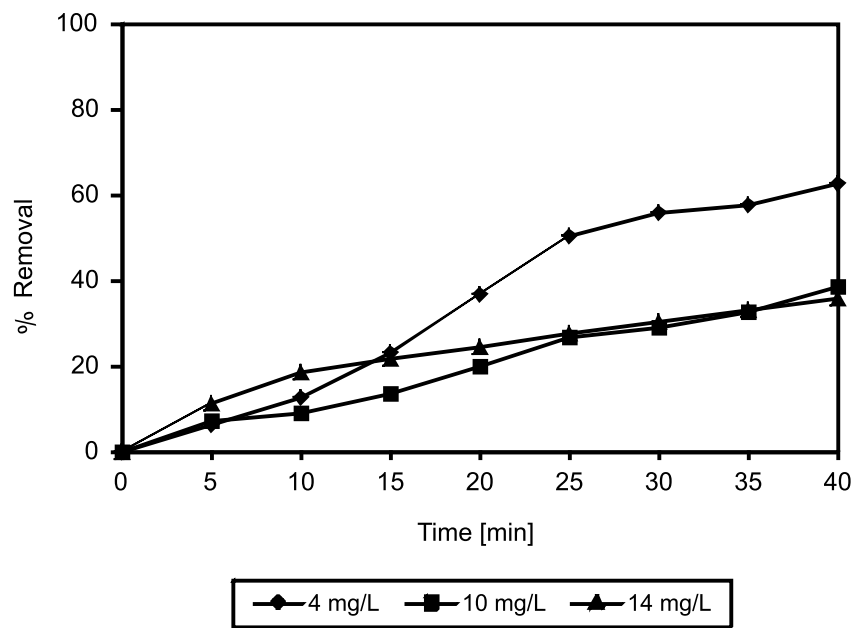

Figure 5. Effect of PC concentration on removal of $\mathrm{PC}$ by DCTW [DCTW] $0=2 \mathrm{~g} / 250 \mathrm{~mL} ; \mathrm{pH}=$ $6.5 ; \mathrm{T}=25^{\circ} \mathrm{C}$

\section{Temperature}

Adsorption of PC onto DCTW was investigated at various temperatures to study the effect of temperature. The efficiency of adsorption decreased with temperature (Fig. 6), because at higher temperatures, the mobility of molecules increased and desorption was occurred ${ }^{19-20}$.

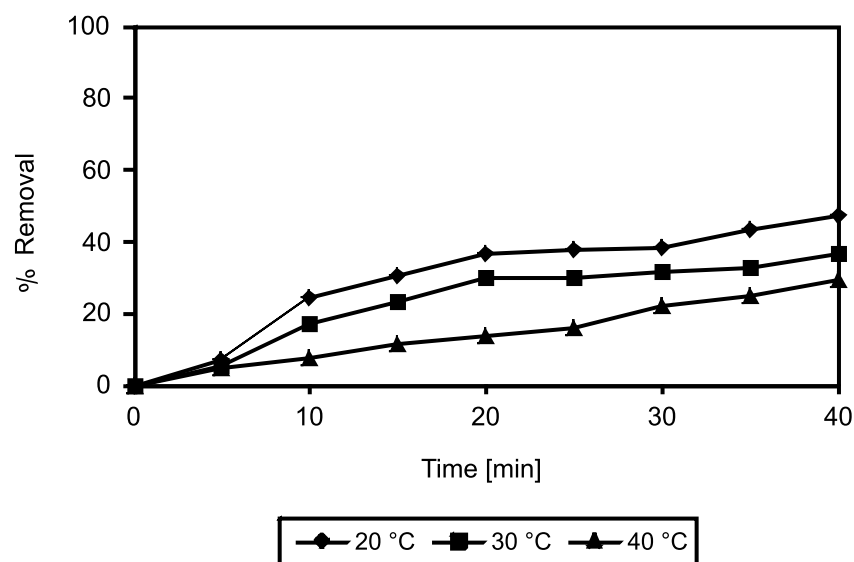

Figure 6. Effect of temperature on removal of PC by $\mathrm{DCTW}[\mathrm{PC}] 0=10 \mathrm{mg} / \mathrm{L} ;[$ DCTW] $0=2 \mathrm{~g} /$ $250 \mathrm{~mL} ; \mathrm{pH}=6.5$

\section{Isotherms equations}

A variety of isotherm equations can be used to explain experimental sorption data. In this paper, Langmuir, Freundlich, and Temkin models were used to depict the relation of adsorbed PC and the corresponding equilibrium concentration.

The isotherm parameters were evaluated by non-linear trial-and-error method using polymath 6.10 software with results shown in Table 1. All models were assumed to be non-linear to minimize the error of variance. The parameters of models $\left(R^{2}, R_{a d j}^{2} S^{2}, R_{m s d}\right)$, were shown at $95 \%$ of confidence interval in Table 1 . If the correlation coefficient value was close to 1 and $\mathrm{R}^{2}$ adj , the regression model was considered correct. The results of Langmuir, Freundlich, and Temkin models are shown in Figure 7.

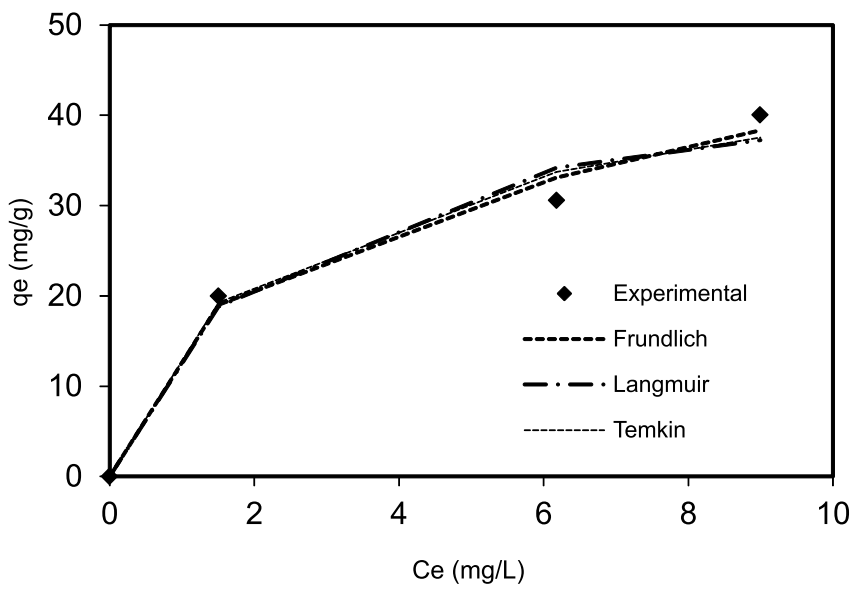

Figure 7. Comparison of Lngmuier, Frundlich and Temkin isotherm models for removal of PC by DCTW

\section{The Langmuir isotherm}

One of the simplest and most widely used isotherms is the Langmuir isotherm. This isotherm assumes that the surface of the sorbent is completely uniform. The Langmuir equation can be described as follows:

$q_{e}=\frac{q_{m} K_{L} C_{e}}{1+K_{L} C_{e}}$

Here, $q_{e}$ is the amount of adsorbate at equilibrium $(\mathrm{mg} / \mathrm{g}), C_{e}$ is equilibrium concentration of solute $(\mathrm{mg} / \mathrm{L})$, $q_{m}$ is the maximum adsorption capacity $(\mathrm{mg} / \mathrm{g})$ and $K_{L}$ is the Langmuir adsorption constant $(\mathrm{L} / \mathrm{mg})$. Affinity between PC and DCTW was obtained using a dimensionless separation factor, $R_{L}$ [21] which indicates the nature of adsorption, such that unfavorable adsorption is when $R_{L}>1$, linear adsorption is when $R_{L}=1$, and favorable adsorption is when $0<R_{L}<1$, and irreversible adsorption is when $R_{L}=0$.

It can be seen from Table 1 , that the $\mathrm{R}^{2}$ value $\left(\mathrm{R}^{2}=\right.$ 0.9750 ) is not enough close to 1 and, therefore, the Langmuir isotherm model is not able to fit the sorption data.

Table 1. Isotherm parameters and error deviation data for PC adsorption onto DCTW

\begin{tabular}{|l|c|c|c|c|c|c|}
\hline Model & $R^{2}$ & $R_{a d j}^{2}$ & $R m s$ & $s^{2}$ & Parameters & Values \\
\hline Langmuir & 0.975 & 0.962 & 11.174 & 11.042 & $q_{m}(\mathrm{mg} / \mathrm{g})$ & $46.3565( \pm 0.0038)$ \\
\hline & & & & & $K_{L}(\mathrm{~L} / \mathrm{mg})$ & $K_{F}\left[(\mathrm{mg} / \mathrm{g})(\mathrm{L} / \mathrm{mg})^{1 / n}\right]$ \\
\hline Freundlich & 0.988 & 0.982 & 0.793 & 5.042 & $n$ & $16.2122( \pm 0.0001)$ \\
\hline & & & & & $B_{1}$ & $2.5535( \pm 0.0060)$ \\
\hline Temkin & 0.981 & 0.972 & 1.015 & 8.247 & $K_{T}(\mathrm{~L} / \mathrm{g})$ & $10.2185( \pm 9.2734)$ \\
\hline & & & & & & $4.3847( \pm 12.1461)$ \\
\hline
\end{tabular}




\section{The Freundlich isotherm}

The Freundlich isotherm model can be applied to describe nonideal sorption on heterogeneous surfaces ${ }^{22}$. Freundlich isotherms are represented by equation 5:

$q_{e}=K_{F} C_{e}^{\frac{1}{n}}$

Where, $C_{e}(\mathrm{mg} / \mathrm{L})$ is the concentration of solute at equilibrium, $q_{e}(\mathrm{mg} / \mathrm{g})$ is the amount of equilibrium adsorbed of solute, $K_{F}[\mathrm{~L} / \mathrm{g}]$ and $\mathrm{n}$ are the Freundlich constants indicating adsorption capacity and intensity, respectively, and $1 / \mathrm{n}$ is a constant (dimensionless) that refers to the adsorption intensity or the factors that describes reversible adsorption ${ }^{23}$. If $n=1$, this indicates that the partition of two phases are independent of concentration and the adsorption isotherm can be reduced to a linear form. If $1<\mathrm{n}<10$, this indicates a favorable sorption process ${ }^{24}$.

Table 1 shows that the value of $1 / n=0.392(n=2.553)$, which indicates that adsorption of PC onto DCTW is favorable. The higher $R^{2}$ value $\left(R^{2}=0.9886\right)$ for this isotherm also confirms that the adsorption of PC onto DCTW is fit well with the Freundlich isotherm model.

\section{The Temkin isotherm}

The Temkin isotherm assumes that the adsorption heat of all molecules in the layer would decrease linearly rather than logarithmically with coverage ${ }^{24}$. The model is expressed by the following equation ${ }^{25}$.

$q e=\frac{R T}{b_{T}} \ln \left(K_{T} C_{e}\right)$

$B=\frac{R T}{b_{T}}$

Where, $K_{T}$ is the Temkin equilibrium binding constant $(\mathrm{L} / \mathrm{g}), b$ is Temkin constant, $R$ is the ideal gas constant $(8.314 \mathrm{~J} / \mathrm{mol} / \mathrm{K}), T$ is temperature in Kelvin $(298 \mathrm{~K})$ and $B$ is a constant related to heat of sorption $(\mathrm{J} / \mathrm{mol})$. Temkin parameters were estimated as $K_{T}=4.3847 \mathrm{~L} / \mathrm{g}$, $B=10.2185 \mathrm{~J} / \mathrm{mol}$, with an $\mathrm{R}^{2}=0.9813$. The estimated value for $B$ confirms that there is a physical adsorption process $^{24}$.

\section{Adsorption kinetic}

In this study, two kinetic models were examined to determine the kinetic adsorption of PC onto DCTW, pseudo- first- and -second-order kinetic models ${ }^{17}$.

Forms of these two models are present in following equations, respectively;

$q_{t}=q_{e}\left(1-e^{-k t_{1}}\right)$

$q_{t}=\frac{q_{e}^{2} k_{2} t}{1+k_{2} q_{e} t}$

Here, qt is amount of adsorbed PC onto DCTW $(\mathrm{mg} / \mathrm{g})$ at contact time $\mathrm{t}$ and qe is amount of adsorbed PC onto DCTW $(\mathrm{mg} / \mathrm{g})$ at equilibrium time and $k_{1}\left(\mathrm{~min}^{-1}\right)$ and $k_{2}$ (g/mg $\mathrm{min}$ ) are the pseudo-first- and -second-order constants, respectively. All parameters of the models were obtained at $95 \%$ confidence using polymath 6.10 software and results are shown in Table 2. Figure 8 shows the experimental data and results of the two kinetic models.

It can be concluded that the pseudo-first order model, with an $\mathrm{R}^{2}$ of 0.9916 , provided a better fit with to the data than the pseudo-second order model.

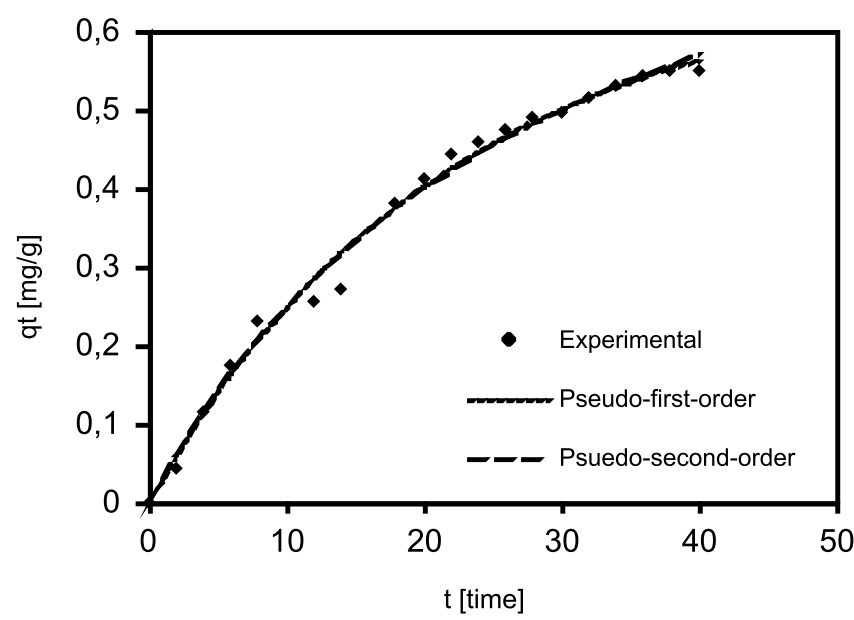

Figure 8. Comparison of kinetic models for removal of PC by DCTW

\section{CONCLUSION}

Green tea is largely consumed around the globe and is considered the second most popular beverage in the world after water. Hence, the utilization of such waste is most desirable. Therefore, the use of spent tea waste an abundantly available solid waste be economically and technically feasible. In this paper, removal of PC onto DCTW from aqueous solutions was studied. Based on the results obtained, DCTW appears to be an effective bioadsorbent for removal of PC from aqueous solutions. Adsorption of DCTW onto PC was fitted using a Freundlich isotherm and followed by a pseudo-first-order kinetic model. The amount of PC adsorbed varied with contact time, $\mathrm{pH}$, and concentration of $\mathrm{PC}$, temperature, and DCTW dosage. The maximum adsorption of PC by DCTW occurred at a $\mathrm{pH}$ of 3 and adsorption reached equilibrium after $40 \mathrm{~min}$ of contact time. So, it is recommended to use of tea waste as a cheap and environmentally friendly adsorbent in removal of organic pollutants from aqueous solutions.

\section{ACKNOWLEDGEMENTS}

The authors would like to appreciate Ahar Branch, Islamic Azad University for the financial support of this research, which is based on a research project contract.

Table 2. Kinetic parameters and error deviation data for PC adsorption onto DCTW

\begin{tabular}{|c|c|c|c|c|c|c|}
\hline Model & $R^{2}$ & $R_{a d j}^{2}$ & $R m s$ & $s^{2}$ & Parameters & Values \\
\hline \multirow[t]{2}{*}{ Pseudo-first order } & 0.991 & 0.990 & 0.003 & 0.003 & $q_{e, c a l}(\mathrm{mg} / \mathrm{g})$ & $0.6719( \pm 0.0004)$ \\
\hline & & & & & $k_{1}\left(\min ^{-1}\right)$ & $0.0624\left( \pm 8.20 \cdot 10^{-5}\right)$ \\
\hline Pseudo-second order & & & & & $k_{2}$ (g/mg.min) & $0.032( \pm 0.0122)$ \\
\hline
\end{tabular}




\section{LITERATURE CITED}

1. Ania, C.O., Pelayo, J.G. \& Bandosz, T. J. (2011). Reactive adsorption of penicillin on activated carbons. Adsorption 17, 421-429. DOI: 10.1007/s10450-010-9271-9.

2. Choi, K.J., Kim, S.G. \& Kim, S.H. (2008). Removal of antibiotics by coagulation and granular activated carbon Filtration. J. Hazard. Mater. 151, 38-43. DOI: 10.1016/j.jhazmat.2007.05.059.

3. Al-Ahmad, A., Daschner, F.D. \& Kummerer, K. (1999). Biodegradability of cefotiam, ciprofloxacin, meropenem, penicillin G, and sulfamethoxazole and inhibition of waste water bacteria. Arch. Environ. Contam. Toxicol. 37, 158-163. DOI: 10.1007/s002449900501.

4. Zümriye, A. \& Özlem, T. (2005). Application of biosorption for penicillin $\mathrm{G}$ removal: comparison with activated carbon. Process Biochem. 40, 831-847. DOI: 10.1016/j.procbio.2004.02.014.

5. Chaubal, M.V., Payne, G.F., Reynolds, C.H. \& Albright, R.L. (1995). Equilibria for the adsorption of antibiotics onto neutral polymeric sorbents: Experimental and modeling studies. Biotechnol. Bioeng. 47, 215-226. DOI: 10.1002/bit.260470213.

6. Zhang, H., Yu, X., Chen, L., Jing, Y. \& Ge, Z. (2010). Study of Ni-63 adsorption on NKF-6 zeolite. J. Environ. Radioact. 101, 1061-1069. DOI: 10.1016/j.jenvrad.2010.08.009. 7. Zuorro, A. \& Lavecchia, R. (2010). Adsorption of $\mathrm{Pb}(\mathrm{II})$ on Spent Leaves of Green and Black Tea. Am. J. Appl. Sci. 7, 153-159. DOI: 10.1016/j.procbio.2005.02.004.

8. Chen, C. \& Wang, J. (2009). Biosorbents for heavy metals removal and their future. Biotechnol. Adv. 27, 195-226. DOI: 10.1016/j.biotechadv.2008.11.002.

9. Arshad Khosa, M., Wua, J. \& Ullah, A. (2013). Chemical modification, characterization, and application of chicken feathers as novel biosorbents. RSC $A d v$. 3, 20800-20810. DOI: 10.1039/C3RA43787F.

10. Srinivasan, A. \& Viraraghavan, T. (2010). Decolorization of dye wastewaters by biosorbents: A review. J. Environ. Manage. 91, 1915-1929. DOI: 10.1016/j.jenvman.2010.05.003.

11. Hameed, B.H. (2009). Spent tea leaves: A new non-conventional and low-cost adsorbent for removal of basic dye from aqueous solutions. J. Hazard. Mater. 161, 753-759. DOI: 10.1016/j.jhazmat.2008.04.019.

12. Uddin, M.T., Islam, M.A., Mahmud, S. \& Rukanuzzaman, M. (2009). Adsorptive removal of methylene blue by tea waste. J. Hazard. Mater. 164, 53-60. DOI: 10.1016/j.jhazmat.2008.07.131.

13. Yang, X. \& Cui, X. (2013). Adsorption characteristics of $\mathrm{Pb}$ (II) on alkali treated tea residue. Water Resour. Ind. 3, 1-10. DOI: 10.1016/j.wri.2013.05.003.

14. Amarasinghe, B.M.W.P.K. \& Williams, R.A. (2007).Tea waste as a low cost adsorbent for the removal of $\mathrm{Cu}$ and $\mathrm{Pb}$ from wastewater. Chem. Eng. J. 132, 299-309. DOI: 10.1016/j. cej.2007.01.016.

15. Cay, S., Uyanik, A. \& Ozasik, A. (2004). Single and binary component adsorption on copper (II) and cadmium (II) from aqueous solution using tea industry waste. Sep. Purif. Technol. 38, 273-280. DOI: 10.1016/j.seppur.2003.12.003.

16. Wasewar, K.L., Atif, M., Prasad, B. \& Mishra, I.M. (2009). Batch adsorption of $\mathrm{Zn}$ on tea factory waste. Desalination 244, 66-71. DOI: 10.1016/j.desal.2008.04.036.

17. Mohammad, A.H. \& Md, S.A. (2012). Adsorption kinetics of Rhodamine-B on used black tea leaves. Iranian J. Environ. Health Sci. Eng. 9, 1-7. DOI: 10.1186/1735-2746-9-2.

18. Jeyakumar, R.P.S. \& Chandrasekaran, V. (2014). Adsorption of lead(II) ions by activated carbons prepared from marine green algae: Equilibrium and kinetics studies. Inter. J. Indu. Chem. 5, 1-10. DOI:10.1186/2228-5547-5-2.

19. Chen, D.Z., Zhang, J.X. \& Chen, J.M. (2010). Adsorption of methyl tert-butyl ether using granular activated carbon: Equilibrium and kinetic analysis. Int. J. Environ. Sci. Tech. 7, 235-242. DOI: 10.1007/BF03326133.
20. Pandey, P.K., Sharma, S.K. \& Sambi, S.S. (2010). Kinetics and equilibrium study of chromium adsorption on zeolite $\mathrm{NaX}$. Int. J. Environ. Sci. Tech . 7, 395-404. DOI: 10.1007/BF03326149.

21. Tseng, R.L. \& Wu, F.C. (2009). Analyzing concurrent multi-stage adsorption process of activated carbon with a favorable parameter of Langmuir equation. J. Taiwan Inst. Chem. E. 40, 197-204. DOI: 10.1016/j.jtice.2008.09.002.

22. Ho, Y.S., Porter, J.F. \& Mckay, G. (2002). Equilibrium isotherm studies for the sorption of divalent metal ions onto peat: copper, nickel and lead single component systems. Water Air Soil Poll. 141, 1-33. DOI: 10.1023/A:1021304828010.

23. Ahmed Dhahir, S. \& AL-Saade, K.A. (2013). Adsorption study of rhodamin $\mathrm{b}$ dye on iraqi bentonite and modified bentonite by nanocompounds $\mathrm{TiO} \mathrm{ZnO}, \mathrm{Al} 2 \mathrm{O} 3$, sodium dodecyl sulfate. Am. J. Environ. Sci. 9, 269-279. DOI: 10.3844/ ajessp.2013.269.279.

24. Zheng, H., Liu, D., Zheng, Y., Liang, S. \& Liu, Z. (2009). Sorption isotherm and kinetic modeling of aniline on Cr-bentonite. J. Hazard. Mater. 167, 141-147. DOI: 10.1016/j. jhazmat.2008.12.093.

25. Tosun, I. (2012). Ammonium Removal from Aqueous Solutions by Clinoptilolite: Determination of Isotherm and Thermodynamic Parameters and Comparison of Kinetics by the Double Exponential Model and Conventional Kinetic Models. Int. J. Environ. Res. Pub. Health. 9, 970-984. DOI: 10.3390/ijerph9030970. 